Krzysztof Moraczewski

ORCID: 0000-0002-8919-2568

Uniwersytet im. Adama Mickiewicza w Poznaniu

\title{
Muzyka instrumentalna i język. Stanowisko Herdera w osiemnastowiecznej debacie muzyczno-estetycznej
}

Abstrakt: Filozofia muzyki zawarta w pismach Johanna Gottfrieda Herdera podejmuje dwa zasadnicze wątki osiemnastowiecznej debaty muzyczno-estetycznej: relację muzyki i języka oraz status muzyki instrumentalnej. Umieszczone na mapie zajmowanych w tej debacie stanowisk poglądy Herdera cechują się nie tylko odmiennością proponowanych rozwiązań, ale przede wszystkim zdolnością przekroczenia horyzontu samej debaty, umożliwiającego wyjaśnienie podstaw możliwości oraz zakresu ważności poszczególnych koncepcji. Fundament koncepcji Herdera stanowią trzy elementy: idea językowej prefiguracji znaczeń dla muzyki instrumentalnej, przekonanie o językowym charakterze percepcji zmysłowej oraz wizja opartej na tych dwóch elementach jednolitej hermeneutyki dla sztuk nielingiwstycznych.

Słowa-klucze: Herder, kultura, język, hermeneutyka, muzyka instrumentalna, estetyka

\section{Zmiany w interpretacji poglądów Herdera}

Olbrzymi wysiłek interpretacyjny włożony w ostatnich dziesięcioleciach w ponowne przyswojenie myśli Johanna Gottfrieda von Herdera oraz w przebadanie jej konsekwencji w ukształtowaniu się w kręgu niemieckojęzycznym zarówno wyspecjalizowanej etnografii, jak i szerzej — nauk o duchu i nauk o kulturze w ogólności, zaowocował nie tylko obszerną literaturą przedmiotu, ale też kluczowymi ustaleniami merytorycznymi.

Po pierwsze, wyjaśnione zostały nieporozumienia wynikające z przyjmowania jako koncepcji Herderowskich tych ustaleń, które Herder prezentował we wczesnych pismach, a następnie zrewidował lub wręcz odrzucił, a które tradycyjnie pre- 
zentowane były jako jego stanowisko ${ }^{1}$. W głównej mierze dotyczy to porzucenia przez Herdera transcendentalnego i apriorycznego punktu widzenia na rzecz podejścia historyczno-kulturowego i etnograficznego. Zmiana ta ma szczególne znaczenie dla estetyki Herdera, w odniesieniu do której nie można już dłużej przyjmować jako punktu wyjścia apriorycznych rozważań zawartych we wczesnych pismach, przede wszystkim w obszernych partiach Gajów krytycznych, reprezentujących właśnie owo zrewidowane później podejście aprioryczne, pozwalające błędnie umieścić rozważania Herdera w kręgu pozornie pokrewnych koncepcji Alexandra Baumgartena, Johanna Georga Hamanna i Immanuela Kanta.

Po drugie, rozwiano nieporozumienia wynikające stąd, że niektóre przynajmniej terminy używane przez Herdera nabrały w XIX wieku znaczeń zupełnie odmiennych od tych, które wiązał z nimi sam Herder, co prowadziło do poważnych nieporozumień interpretacyjnych. Kwestia ta dotyczy w głównej mierze terminów takich jak ,naród” czy „lud”, które rozumiano intuicyjnie w duchu dziewiętnastowiecznego nacjonalizmu, całkowicie obcego myśli Herdera ${ }^{2}$. Wiadomo już dziś, że jeśli Herder promował „nacjonalizm”, to chodziło w nim o odkrycie i dowartościowanie językowo i kulturowo odrębnych sposobów realizacji człowieczeństwa, których wyjątkowość niknie za parawanem ogólnoeuropejskiej kultury elitarnej, a zarazem o odkrycie i dowartościowanie owych etnicznie specyficznych kultur nieuprzywilejowanych warstw ludności. Był to więc „nacjonalizm” opierający się na afirmacji różnicy, na emancypacji stłumionych zdaniem Herdera możliwości kulturowych i nic nie miał wspólnego z tą formą nacjonalizmu, która jako polityczna ideologia miała stać się w dziesięcioleciach po Herderze narzędziem polityki państw narodowych. Współgra z tą dominującą dzisiaj interpretacją fakt, że w swej filozofii politycznej Herder był jedynym chyba w osiemnastowiecznych Niemczech zdecydowanym obrońcą demokracji.

Po trzecie, nowe ustalenia pozwoliły na dokładniejszą interpretację jego koncepcji kultury i jej historyczności. Koncepcja ta była bowiem interpretowana albo jako protoewolucjonistyczna, albo jako wręcz teologiczna, a przynajmniej historiozoficzna. Pierwsza ścieżka interpretacyjna reprezentowana była wielokrotnie przez socjologów oraz antropologów i czyniła z Herdera jednoznacznego protoplastę rozwijanych następnie koncepcji antropologii ewolucyjnej, przede wszystkim tych nastawionych bardziej „mentalnościowo”, a więc na przykład koncepcji Johanna Jakoba Bachofena, Edwarda Burnetta Tylora czy Jamesa Frazera. W Polsce taką interpretację prezentowała Antonina Kłoskowska ${ }^{3}$ i w jej ujęciu domniemany

${ }^{1}$ Szczegółowego, ale sumarycznego stanu interpretacji poglądów Herdera dokonał Michael Forster, Johann Gottfried von Herder, [hasło w:] The Stanford Encyclopedia of Philosophy (Summer 2019 Edition), red. E.N. Zalta, https://plato.stanford.edu/archives/sum2019/entries/herder/ (dostęp: 4.03.2021).

2 Szczegółowe omówienie filozofii politycznej Herdera w kontekście współczesnej mu myśli znajduje się w: F.C. Beiser, Enlightenment, Revolution, and Romanticism: The Genesis of Modern German Political Thought, 1790-1800, Cambridge 1992.

3 A. Kłoskowska, Socjologia kultury, Warszawa 1981, s. 17-18. 
Herderowski ewolucjonizm jawił się jako o wiele dojrzalszy i łatwiejszy do uzgodnienia $\mathrm{z}$ biologicznym rozumieniem ewolucji niż mylone z sobą pojęcia ewolucji i postępu ujęcia Frazera czy Henry’ego Lewisa Morgana. Z drugiej strony, rozważania zawarte w Myślach o filozofii dziejów pozwalały przypisać Herderowi przeciwstawną wręcz wizję dziejów, jako zawierających własny wewnętrzny cel i stanowiących czasowe rozwinięcie immanentnego sensu. Można było ją więc rozumieć jako koncepcję zapowiadającą historiozofię Hegla albo wręcz jako pewną postać teologii dziejów. Nietrudno zauważyć, że możliwe interpretacje wydają się nie do pogodzenia. Nowy wysiłek interpretacyjny pozwolił dopiero ustalić relację między dziejami kultury jako pewną formą biologicznej adaptacji gatunku ludzkiego a sposobem rozumienia tej samej historii przez przeżywających ją ludzi w ich odniesieniu do siebie nawzajem, własnej pamięci i — oczywiście — własnych idei religijnych, w której to relacji konstytuuje się dopiero celowość i sensowność historii jako realizacji człowieczeństwa ${ }^{4}$. Herderowska koncepcja dziejów jest zatem w dzisiejszej interpretacji o wiele bardziej złożona i wielostronna, niż sugerowały jednostronne wcześniejsze interpretacje. Jeśli szukać jej następców, to wśród autorów takich jak Arnold Toynbee, którzy z podobną rzetelnością starali się uchwycić i wyjaśnić relację między zdeterminowanym charakterem wydarzeń a ich ludzkim usensownianiem - autorów, którzy niekoniecznie doczekali się już sprawiedliwej interpretacji.

\section{Muzyka jako problem w myśli Herdera}

Wciąż pozostały jednak całe pola myśli Herderowskiej, które dopiero domagają się głębszej interpretacji, całe sfery oddziaływania, w których ferment wywołany przyswojeniem Herdera nie został jeszcze opisany i wyjaśniony inaczej niż tylko wstępnie. Dotyczy to niektórych działów estetyki, w tym zwłaszcza filozofii muzyki. Charakterystyczne i zadziwiające, że najpopularniejszy podręcznik w tym zakresie, czyli Historia estetyki muzycznej Enrica Fubiniego, nie zawiera choćby podrozdziału dotyczącego Herdera, a samo jego nazwisko jest wspomniane w owej książce ledwie pięciokrotnie, w tym tylko raz szerzej, w odrębnym, poświęconym Herderowi akapicie ${ }^{5}$. Spośród głównych podręczników do historii muzyki większość nie wymienia Herdera w ogóle. Wyjątkiem w tym zakresie jest The Oxford History of Western Music Richarda Taruskina ${ }^{6}$. Amerykański muzykolog przywiązuje odpowiednią wagę do znaczenia, jakie koncepcja Herde-

${ }^{4}$ Zob. J.H. Zammito, Herder and Historical Metanarrative: What's Philosophical about History?, [w:] A Companion to the Works of Johann Gottfried Herder, red. H. Adler, W. Koepke, Rochester-New York 2009, s. 65-92.

${ }^{5}$ E. Fubini, Historia estetyki muzycznej, przeł. Z. Skowron, Kraków 2002, s. 256-257.

${ }^{6}$ R. Taruskin, The Oxford History of Western Music, t. 3. Music in the Nineteenth Century, Oxford-New York 2010, s. 120-124. 
ra miała dla samej możliwości ukształtowania się niemieckiej, a potem w ogóle środkowo- i wschodnioeuropejskiej muzyki romantycznej, szczególnie podkreślając wprowadzenie zasadniczej idei odmienności kulturowej i odkrycie znaczenia kultur nieelitarnych dla ukształtowania się ideału Volkstümlichkeit. Nawet jednak Taruskin, skądinąd tak przenikliwy w dostrzeganiu związków między praktykami muzycznymi a innymi sferami działalności kulturowej, pomija milczeniem właściwą filozofię muzyki Herdera, odwołując się jedynie do ogólnej teorii kultury, koncepcji kultury ludowej i dorobku etnograficznego samego Herdera oraz jego kontynuatorów, przede wszystkim Wilhelma Karla Grimma.

Jest bez wątpienia prawdą, że rekonstrukcja Herderowskiej filozofii muzyki wymaga wysiłku i ostrożności. W przedsięwzięciu takim przynajmniej trzy punkty wydają się problematyczne.

Po pierwsze, wiele refleksji Herdera na temat muzyki zawartych jest we wczesnych pismach, przede wszystkim w Gajach krytycznych ${ }^{7}$, a więc były one formułowane, gdy Herder nie porzucił jeszcze apriorycznego i systemowego sposobu uprawiania estetyki. Szczęśliwie niemało z tych uwag szczegółowych zostało przez Herdera powtórzonych lub zrewidowanych we fragmentach późniejszych pism, co umożliwia dokładniejszą interpretację.

Po drugie, Herderowska filozofia muzyki jest najściślej powiązana z filozofią języka, co z jednej strony uniemożliwia jej wyizolowanie, z drugiej jednak pozwala poszukiwać wielu twierdzeń na temat muzyki implikowanych przez tezy z zakresu filozofii języka. Ułatwia to podejmowanie decyzji co do tego, które z wczesnych, apriorycznych twierdzeń Herdera na temat muzyki należałoby utrzymać także w kontekście jego późniejszej filozofii.

Po trzecie wreszcie, filozofia muzyki Herdera do osiągnięcia jej pełnej zrozumiałości i określenia jej doniosłości wymaga prawidłowego umieszczenia w kontekście tych zagadnień, które zainicjowane często dużo wcześniej, decydowały o hierarchii problemów filozofii muzyki w drugiej połowie osiemnastego wieku. Dopiero w kontekście ówczesnych debat estetycznych ujawnia się cała oryginalność ujęcia Herdera: oryginalność, która wciąż jeszcze domaga się pełnego przyswojenia. Poniżej zajmę się przede wszystkim trzecim z tych zagadnień, to jest miejscem Herderowskiej filozofii muzyki na mapie zasadniczych debat estetycznych drugiej połowy XVIII wieku, sięgając do innych zagadnień tylko o tyle, o ile wymusza to tak określony zasadniczy problem.

Pole problemowe, w którym mieści się Herderowskie ujęcie muzyki, wyznaczane jest przez trzy zasadnicze zagadnienia. Najpierw — i jest to zagadnienie specyficznie Herderowskie, owocujące w pełni dopiero w następnych dziesięcioleciach — jest to kwestia kulturowej specyfiki sposobu bycia pewnego ludu,

7 J.G. Herder, Gaje krytyczne, czyli rozważania dotyczące nauki i sztuki piękna, podane wedtug nowszych pism, [w:] idem, Wybór pism, przeł. M. Jaroszewski, Wrocław 1987, s. 40-53. Zob. M. Fijałkowski, Pieśń ludowa u Johanna Gottfrieda Herdera. Impulsy, źródła, recepcja, Warszawa 2017. 
który to sposób bycia wyraża się w jednolitym geście wyrazowym, jakim jest pieśń. Koncepcja pieśni jako nie syntezy słowa i dźwięku muzycznego, ale pierwotnie jednolitego gestu otwiera natychmiast drugie zagadnienie, czyli kwestię relacji muzyki i języka. Wreszcie ujęcie muzyki jako pozostającej w szczególnym związku z językiem wymusza wręcz zmierzenie się z nowym w drugiej połowie XVIII wieku zjawiskiem, czyli z gwałtownym rozwojem muzyki instrumentalnej. Te trzy kwestie, a zwłaszcza druga i trzecia z nich, pojawiają się jako kluczowe elementy w każdej istotnej filozofii muzyki interesującej nas epoki. Pozostają aktualne o tyle, o ile wciąż należymy — przynajmniej w naszej muzyce artystycznej — do epoki otwartej przez to właśnie wielkie wydarzenie, jakim było pełne usamodzielnienie się muzyki instrumentalnej. Jeśli jednak każdy istotny myśliciel zajmujący się wówczas muzyką rozważa te zagadnienia, to chyba tylko jeden filozof zauważył przed Herderem fakt, jak głęboko są one ze sobą powiązane, i to, że nie można rozpatrywać ich osobno. Filozofem tym był oczywiście Jean-Jacques Rousseau i to już wystarcza, aby ustanawiać między filozofiami muzyki Rousseau i Herdera szczególną więź, tym mocniej zresztą uwypuklającą zachodzące między nimi zasadnicze rozbieżności.

\section{Pierwotność pieśni: Rousseau i Herder}

Koncepcja pieśni jako pierwotnej postaci języka jest wspólna Herderowi i Rousseau. Obydwaj filozofowie zakładają, że u podstaw ludzkiej ekspresji stał jednolity gest wyrazowy, w którym elementy znane później jako poetyckie i muzyczne nie były oddzielone, więc nie prowokowały w ogóle pytania o relację słowa i dźwięku muzycznego. Nie zawsze zauważa się, jak zasadniczą rewizję wcześniejszych poglądów na tę kwestię stanowił punkt widzenia Rousseau i Herdera. Tradycyjne ujęcie tej kwestii zostało bowiem ustanowione w wieku XVI, a potwierdzone i przekształcone w oczywistość funkcjonującą jak aksjomat w teorii muzyki na początku wieku XVII (pomijamy tutaj z braku miejsca złożoną historię tego problemu w myśli antycznej i średniowiecznej, skupiając się jedynie na najistotniejszej w usytuowaniu myśli Herdera tradycji nowożytnej).

U początku owego rozstrzygnięcia stoi seria pytań zadanych przez Vincenza Galileiego, dotyczących relacji między musica moderna, czyli polifonią franko-flamandzką i jej kontynuacjami, a musica antica, czyli znanym jedynie pośrednio światem starożytnej muzyki greckiej ${ }^{8}$. Sprzeczność, jaką ojciec Galileusza dostrzega między musica moderna a musica antica, zasadza się na emancypacji i autonomii konstrukcji dźwiękowej w muzyce polifonicznej. Muzyka ta, jako formalna konstrukcja dźwiękowa, z konieczności ignoruje czynnik poetycki, któ-

${ }^{8}$ Zob. dokładne omówienie w S. Sadie, Vincenzo Galilei, [hasło w:] The New Grove Dictionary of Music and Musicians, t. 20, London 1980. 
rego prawidła kształtowania są odmienne od reguł formy muzycznej. Poświęcając kształtowanie poetyckie, będące przede wszystkim kształtowaniem znaczeń, i traktując słowo jedynie jako brzmienie podlegające muzycznemu zakomponowaniu, muzyka polifoniczna jest w stanie osiągnąć doskonałość czysto muzycznej konstrukcji formalnej, dokonuje tego jednak za cenę odebrania samej muzyce istotności. Będąc jedynie doskonałą konstrukcją wzniesioną z dźwięków, muzyka ta może tylko przynosić satysfakcję zmysłowemu postrzeganiu, a tracąc wszelką doniosłość moralną i myślową, staje się przedmiotem hedonizmu, może nieco bardziej wyszukanego niż hedonizmy innego rodzaju. W przeciwieństwie do musica moderna w świecie starożytnej muzyki greckiej obowiązywała zdaniem Galileiego odwrotna relacja: dominacja kształtowania poetyckiego, któremu podporządkowane było kształtowanie muzyczne, pełniące jedynie funkcję instrumentalną, co umożliwiało nie tylko zachowanie, ale wręcz pogłębienie - poprzez nadanie jej zmysłowej bezpośredniości — mocy moralnego i myślowego oddziaływania poezji. Świadectwem mocy musica antica są przy tym przede wszystkim filozoficzne greckie koncepcje etosu muzyki, wywodzące się z tradycji pitagorejskiej i platońskiej, które nie mogłyby być sensownie zastosowane do hedonistycznego świata musica moderna. Dominacja kształtowania muzycznego zniweczyła muzyczną moc musica antica, a jej odzyskanie — to już artystyczny projekt Galileiego i jego środowiska — staje się zadaniem, które wymaga w pierwszym rzędzie odrzucenia tradycji polifonicznej i ma być zrealizowane w nowym, monodycznym stile recitativo. Mniejsze ma dla nas znaczenie historyczna prawdziwość wywodów Galileiego w odniesieniu do muzyki starogreckiej. Istotniejsze jest to, że Galilei ustanawia relację muzyki i poezji jako czynników nie tylko rozdzielonych, lecz wręcz konfliktowych. Odmienność reguł i celów kształtowania muzycznego i poetyckiego powoduje, że w każdym ich połączeniu jeden $z$ dwóch czynników musi być władającym i narzucać drugiemu swoje cele i reguły, przy czym sam Galilei w dominacji czynnika muzycznego nie widzi walorów innych niż hedonistyczne.

Pogląd Galileiego stał się oczywistością nowożytnych koncepcji muzyki. Już na początku XVII wieku istotność tego schematu myślowego potwierdzają polemiki wokół madrygałów Claudia Monteverdiego ${ }^{9}$. Zostały one zaatakowane przez Giovanniego Marię Artusiego, wybitnego teoretyka muzyki, jako przykład pogwałcenia zasadniczych reguł harmonii konstrukcji dźwiękowej. Obrona podjęta przez kompozytora i jego brata, Giulia Cesare Monteverdiego, wskazywała na nietrafność zarzutów Artusiego ze względu na to, że w madrygałach obowiązują poetyckie, a nie muzyczne zasady kształtowania. Kompromis, który miał trwać dwa stulecia, zasadzał się na odróżnieniu dwóch porządków sztuki muzycznej: prima prattica, w której czynnik poetycki podporządkowany jest muzycznemu

${ }^{9}$ Zob. dokładne omówienie w: C.V. Palisca, The Artusi-Monteverdi Controversy, [w:] The Monteverdi Companion, red. D. Arnold, N. Fortune, New York 1972. 
i kontynuuje się zmodyfikowany styl polifonii franko-flamandzkiej, oraz seconda prattica, której zasadę najdobitniej wyraził Monteverdi, twierdząc, że „mowa jest panią harmonii, a nie jej sługą". Trwałe utrzymywanie się prima prattica miało wiele wspólnego z sankcją, jaką ta forma muzyki otrzymała zarówno w dekretach Soboru Trydenckiego, jak i w pismach Marcina Lutra. Nawet jeśli sam Monteverdi zapoczątkował w swoich Vespro della Beata Virgine proces syntezy obu muzycznych praktyk, kontynuowany potem między innymi przez Heinricha Schütza i Johanna Sebastiana Bacha, to synteza ta pojmowana była wciąż jako proces udatnego dodania do siebie dwóch zasadniczo obcych żywiołów: poetyckiego i muzycznego. Cały kunszt barokowej retoryki muzycznej, to, co niemiecka muzykologia określiła jako Affektenlehre, opierał się na poszukiwaniu reguł ustanawiających korelację między muzyką a poezją, zasadniczo odmiennymi i dopiero wymagającymi uzgodnienia, dla których wspólny mianownik stanowi racjonalistyczna teoria afektów.

Dopiero gdy uświadomimy sobie, że takie właśnie rozstrzygnięcie traktowane było w artystycznej muzyce naszego kontynentu jako aksjomat, zrozumiemy całą doniosłość stanowiska zajętego przez Rousseau i Herdera - wymaga ono bowiem rewizji samych podstaw europejskiego myślenia o muzyce. Ujęcia Rousseau i Herdera są jednak odmiennie rozwinięte. Wedle Rousseau pierwotność przynależy jednolitemu aktowi żywej mowy, w którym w pełni uobecnia się mówiący podmiot, najpierw poprzez ekspresję uczuć za pomocą dźwięków. Rozdzielenie czynnika językowego i muzycznego dokonuje się poprzez wyabstrahowanie z pierwotnej mowy i oddzielenie od siebie jej dwóch aspektów: logicznego i ekspresywnego ${ }^{10}$. W jednolitym akcie mowy aspekty te przejawiają się odpowiednio jako syntaktyczna, gramatyczna i semantyczna organizacja wypowiedzi oraz jako intonacja. Rzec można, że język jest wyabstrahowanym, logicznym elementem mowy, podczas gdy muzyka stanowi usamodzielnienie jej aspektu ekspresywnego; muzyka pozostaje więc zasadniczo zrozumiała na mocy swojego pochodzenia od bezpośrednio ekspresywnej intonacji mowy. Czynnikiem, który umożliwił tego rodzaju podział, jest pojawienie się pisma. Pismo dokonuje bowiem wydzielenia logicznego elementu mowy przez swą niezdolność do utrwalenia intonacji w sposób inny niż szczątkowy: znaki przestankowe, które zawierają ślady dawnej intonacji, ostatecznie artykułują jednak logiczną strukturę wypowiedzi. Swoista dziejowa katastrofa pisma wyznacza początek konfliktu poezji i muzyki, a zatem spory Galileiego czy Monteverdiego nie są bynajmniej bezpodstawne. Ulegają one jednak ograniczeniu o tyle, o ile możliwe i sensowne są jedynie wewnątrz tych społeczności, które posługują się pismem. Z czysto naukowego punktu widzenia istotności koncepcji Rousseau nie sposób przecenić, gdyż ukazuje ona właściwe miejsce samej kwestii relacji słowa i dźwięku muzycznego, ale też granice jej

10 Zob. J.J Rousseau, Szkic o pochodzeniu języków, przeł. B. Banasiak, Kraków 2001; Z. Skowron, Myśl muzyczna Jeana-Jacques'a Rousseau, Warszawa 2010. 
istotności. Stawianie pytania o relację muzyki i słowa poetyckiego w odniesieniu do oralnych kultur muzycznych na sposób właściwy nowożytnej teorii stanowi w tym świetle nieporozumienie, kluczową etnocentryczną barierę, uniemożliwiającą właściwe zrozumienie form ekspresji w kulturach oralnych — kwestie, które weszły w krąg naukowej refleksji bardzo niedawno wraz z tak zwanym zwrotem cyrograficznym $\mathrm{w}$ antropologii.

Herder ujmuje tę kwestię nieco inaczej. W pierwotnym geście semantycznym, którego idea wyrażona została w koncepcji pieśni jako źródła wszelkiego języka, Herdera mniej interesuje późniejsza katastrofa rozdzielenia tego pierwotnego aktu, a bardziej to, że pieśń, jako forma ekspresji i odniesienia się do świata, jest nieuchronnie w najszerszym sensie poetycka, to jest zarazem ekspresyjna, refleksyjna i figuratywna. Pierwotnie bowiem wszystko jest ekspresją, co do tego zgadza się z Rousseau: ,Już jako zwierzę człowiek posługuje się mową. Wszelkie gwałtowne i najgwałtowniejsze $\mathrm{z}$ gwałtownych, bolesne doznania fizyczne, wszelkie intensywne namiętności duszy wyrażają bezpośrednio krzykiem, dźwiękami, dzikimi nieartykułowanymi dźwiękami" "11. Ta sama zasada pierwotnej ekspresywności dźwięku odpowiada także za zasadniczą zrozumiałość muzyki instrumentalnej. „Uderzona struna spełnia swój naturalny obowiązek: dźwięczy, wzywa echo podobnie czującej, nawet wtedy, kiedy nie ma żadnej, nawet kiedy nie spodziewa się i nie oczekuje, że druga jej odpowie" ${ }^{12}$. Właściwy język zachowuje jednak tylko w formie śladu tę ekspresywność dźwięku, rodzi się bowiem — tutaj zgoda z Rousseau już nie sięga - w wyniku zerwania, a nie prostego przedłużenia. Jego geneza tkwi bowiem w specyficznie ludzkiej cesze, jaką jest zdolność — a raczej konieczność - myślenia, wymagająca nazywania czynności i rzeczy. Jeśli zaś myślenie i język są tym samym, to ,pierwszy moment refleksji stał się momentem wewnętrznego powstania języka"13. Język w ścisłym rozumieniu zatem nie jest prostym przedłużeniem dzielonego ze zwierzętami, naturalnego posługiwania się ekspresywnymi dźwiękami, lecz wykorzystaniem dźwięków jako narzędzia refleksji: „Człowiek jest niezależnie myślącą, aktywną istotą, której siły działają progresywnie; dlatego jest stworzeniem posługującym się językiem!"14. Ostatecznie: „Człowiek odczuwa rozumem i mówi myśląc” ${ }^{15}$. Czyni to jednak wobec innych, rozwój języka ma bowiem charakter zarówno refleksyjny, jak i komunikacyjny, co jest biologicznie określone przez wymóg życia stadnego: „Człowiek w swym przeznaczeniu jest stworzeniem stadnym, społecznym, rozwój języka jest więc dla niego naturalny, istotny, konieczny"16.

11 J.G. Herder, Rozprawa o pochodzeniu języka, przeł. B. Płaczkowska, [w:] idem, Wybór..., s. 59.

12 Ibidem, s. 60.

13 Ibidem, s. 135.

14 Ibidem.

15 Ibidem, s. 139.

16 Ibidem, s. 147. 
Pieśń zachowuje pierwotnie ekspresywne funkcje sygnałów dźwiękowych, nadając im zarazem nową funkcję reprezentacji przedmiotów refleksji; reprezentacja zaś jest figuratywna w tym sensie, że sygnały ekspresywne są przeniesione na przedmioty odniesienia (wraz z towarzyszącym temu przeniesieniu wykorzystaniem dla oznaczania przedmiotów zmysłowych tych dźwięków, które same mają bezpośrednio zmysłowy i przez to sugestywny charakter). Środowiskiem takiego użycia języka pozostaje poezja, pieśń zaś uważa Herder za pierwotną formę poezji. Wyraża to dobitnie: „Poezja jest mową ojczystą rodzaju ludzkiego, a mową ojczystą poetów jest pieśń"17. Źródłowy charakter pieśni łączy się zatem z tezą Herdera o figuratywnym charakterze każdej wypowiedzi językowej, także po jej oddzieleniu od pierwotnego kontekstu pieśni. Oznacza to dalej, że tak zwane wypowiedzi dosłowne tworzą ciągi skonwencjonalizowanych, ale rozwijających się, doskonalących się i coraz bardziej złożonych metafor, których figuratywność zatarła w ciągu długotrwałego użycia. Jeśli pamiętamy przy tym, że Herder rozumie znaczenie językowe jako społeczny sposób użycia zdań i słów, to można powiedzieć, że tak zwana dosłowność rodzi się w wyniku stabilizacji i rozwinięcia sposobów używania pierwotnych metafor.

Oczywiście koncepcja pierwotnej figuratywności języka, wiążąca się z jej pochodzeniem od pieśni, może być wyrażona w sposób odmienny, niż uczynił to sam Herder, to znaczy bez odniesienia do koncepcji pierwotnego, jednolitego aktu ekspresji. Przykładowo więc koncepcja języka wyłożona przez Friedricha Nietzschego w eseju $O$ prawdzie $i$ kłamstwie w pozamoralnym sensie $e^{18}$ również ujmuje wszelką wypowiedź językową jako grę metonimii i metafor, których figuratywny charakter zaciera się w użyciu. Podobnie w kognitywnej koncepcji metafory George Lakoff i Mark Johnson ${ }^{19}$ przyjmują, iż jedynie wypowiedzi o przestrzeni fizycznej mają charakter dosłowny, natomiast każda inna wypowiedź opiera się na metaforycznym rzutowaniu wyrażeń dotyczących przestrzeni fizycznej na inne przestrzenie. Ani jednak Nietzsche, ani Lakoff i Johnson, aby objaśnić pierwotny charakter metafory i sposób, w jaki funduje ona wypowiedzi językowe uchodzące za literalne, nie potrzebowali wiązania pierwotnie figuratywnego charakteru języka z jego genetycznym pochodzeniem od jednolitego aktu muzyczno-poetyckiego, jakim jest pieśń.

Także u Herdera owo powiązanie dwóch elementów genezy języka, to jest pieśni i refleksyjności właściwej człowiekowi jako jego differentia specifica, jest dość skomplikowane i można odnieść wrażenie, że Rousseau opracował swoją koncepcję jednolitości pierwotnego aktu ekspresji konsekwentniej. Różnica ta wynika nie tylko z tego, że Herder kwestie pochodzenia języka i pierwotności pieśni

17 J.G. Herder, O początkach pieśni w ogóle, przeł. E. Namowicz, [w:] idem, Wybór..., s. 513.

18 F. Nietzsche, O prawdzie i ktamstwie w pozamoralnym sensie, [w:] idem, Pisma pozostałe 1862-1875, przeł. B. Baran, Kraków 1993.

19 M. Johnson, G. Lakoff, Metafory w naszym życiu, przeł. T. Krzeszowski, Warszawa 2020. 
rozważa osobno i w innych pismach, ale też z odmiennego układu zainteresowań, bowiem kwestia estetycznie najbardziej interesująca leży dla Herdera nie w genetycznej funkcji pieśni, ale w tym, jak następnie układają się relacje między językiem a muzyką, a więc w drugim z wyszczególnionych przez nas pól problemowych. Rousseau traktuje rozpad pierwotnej mowy jako cywilizacyjną katastrofę i widzi naczelne zadanie sztuki w przywróceniu dawnej jedni. Nic więc dziwnego, że filozoficznie najdonioślejszą formą sztuki staje się dla niego opera jako ta postać ekspresji, w której poezja, muzyka i ruch ludzkiego ciała mogą być poddane ponownej syntezie - idea, która ma przed sobą olbrzymią żywotność i to w tym duchu, a nie jako „dodawanie do siebie różnych dziedzin sztuki” należy rozumieć kluczowe idee dziewiętnastowieczne, takie jak Wagnerowski Gesamtkunstwerk czy tezy Lekcji XIII Adama Mickiewicza. Dotyczy to zdaniem Rousseau zwłaszcza opery włoskiej, która w przeciwieństwie do opery francuskiej nie dokonuje prostego i hierarchicznego podporządkowania muzyki retorycznym regułom poezji.

Pozbawiona swojego związku ze słowem, muzyka traci wedle Rousseau ludzką doniosłość, przyczyniając się jeszcze gruntowniej do utrwalenia rozdziału logiki i ekspresji. Zamknięta wewnątrz reguł pozajęzykowych w swym autonomicznym świecie, muzyka zagrożona jest przede wszystkim utratą związku z fundamentalnym doświadczeniem ekspresji mówiącego człowieka, a więc z egzystencjalną i kulturową nieistotnością, jeśli wręcz nie szkodliwością ze względu na wspomniane utrwalanie wywołanego przez pismo podziału. Wszystkie te les sonates et les symphonies to zdaniem genewskiego filozofa $\mathrm{w}$ najlepszym razie pozbawiony znaczenia szmer. Można oczywiście szukać historycznego wyjaśnienia poglądu Rousseau w tym, że nie miał on jeszcze kontaktu z taką muzyką czysto instrumentalną, która by stanowiła wyzwanie dla jego koncepcji. Mało jednak prawdopodobne, by nowe doświadczenia muzyczne mogły naruszyć przekonania Rousseau wynikające przecież z samych podstaw jego koncepcji filozofii kultury.

\section{Język i wartość muzyki instrumentalnej: Rousseau i Kant}

Zauważmy od razu, że stanowiska zajmowane w kwestii relacji słowa i muzyki określają podejście do trzeciego z wyróżnionych przez nas wielkich problemów epoki, czyli do kwestii muzyki instrumentalnej. Jednak w tych dwóch zakresach, to znaczy relacji muzyki i języka oraz oceny muzyki instrumentalnej, nie wystarczy, aby odpowiednio umiejscowić koncepcję Herdera przez odniesienie do Rousseau: równie istotny kontekst wyznaczają rozważania Immanuela Kanta i koncepcje proponowane przez ówczesnych niemieckich poetów.

Stanowisko zajęte w tych kwestiach przez Kanta wymaga starannego oddzielenia Kantowskiej analizy sądu smaku od filozofii sztuki prezentowanej przez kró- 
lewieckiego filozofa; nazbyt łatwo zapomnieć, że analizowane przez Kanta znamiona sądu smaku nie są postulowanymi cechami sztuki. Znamiona sądu smaku, takie jak bezinteresowność, pozapojęciowość, subiektywna powszechność, oparta na sensus communis konieczność i pusta forma celowości konstytuują w odniesieniu do sztuki jedynie sferę pulcritudo vaga, czyli piękna czystego. Otóż piękno czyste ma wedle Kanta bardzo ograniczone odniesienie do sztuki, stosując się jedynie do jej skrajnych form ornamentalnych, takich jak arabeska. Domeną sztuki jest pulcritudo adherens, czyli piękno zależne, a więc piękno w jego związku z pojęciem. Specyficzny związek pojęcia i piękna zawiera się w Kantowskiej koncepcji idei estetycznej ${ }^{20}$. Idee estetyczne są sposobami zmysłowego przedstawienia pojęcia i przez to wykazują dwie fundamentalne cechy. Po pierwsze, są zależne od pojęcia, a więc od rozumu odpowiedzialnego za ustanawianie pojęć, a nie tylko intelektu jako władzy organizacji przedstawień zmysłowych (i sekundarnie, czego Kant nie rozpatruje, od języka jako medium posługiwania się pojęciami); po drugie istnienie pojęcia w idei estetycznej jest specyficznie zmysłowe, a w konsekwencji nie jest możliwe inne niż zmysłowe jego ujęcie, a więc nie może istnieć wypowiedź językowa, która mogłaby w pełni uchwycić lub zastąpić ideę estetyczną. Dalej, jeżeli zdaniem Kanta zasadniczym celem sztuki nie jest realizacja piękna - w sensie wyłożonym w analityce sądu smaku - ale tworzenie i przedstawianie idei estetycznych, a sam geniusz artystyczny może być zdefiniowany jako zdolność ustanawiania idei estetycznych, to wszelka sztuka jest w bardzo złożonej relacji z językiem. Pozostaje zarówno od języka zależna, gdyż odnosi się do zawartego w idei estetycznej pojęcia, jak i ustanawia sferę tego, co pozajęzykowe, nadając pojęciom zmysłowe istnienie i nie mogąc być przedstawiona w sposób adekwatny środkami języka. Wszelkie późniejsze definicje piękna jako zmysłowego istnienia idei czy pozoru estetycznego jako ustanawianej w sztuce rzeczywistości zmysłowej adekwatnej względem pojęcia, a więc kluczowe definicje filozofii sztuki Friedricha W.J. Schellinga i przede wszystkim Georga W.F. Hegla, pozostają zależne od Kantowskiej koncepcji idei estetycznej.

Przy takim pojmowaniu sensu działań artystycznych Kant musiał mieć poważny problem z muzyką, zwłaszcza z muzyką instrumentalną. Nie posiadając inaczej niż przygodnie charakteru przedstawiającego, muzyka albo może zawdzięczać zdolność do przedstawiania idei estetycznych swojemu związkowi z poezją, albo też zachowując samoistność i autonomię — być do przedstawiania idei estetycznych w ogóle niezdolna. W żadnym razie nie powinniśmy traktować tego dylematu jako akademickiej kwestii kantyzmu, ponieważ w XIX wieku stanie się on kluczowym dylematem kompozytorów. Przyjmując bowiem filozoficzne przekonanie o zadaniu sztuki polegającym na nadawaniu zmysłowej rzeczywistości myśleniu, kompozytorzy ci będą zarazem musieli poradzić sobie z paradoksalną sytuacją czystej muzyki instrumentalnej. Będą ją zatem traktowali jako swoisty

20 Zob. I. Kant, Krytyka władzy sądzenia, przeł. J. Gałecki, Warszawa 1986, s. 284-288. 
modus niepełny muzyki — to dlatego Richard Wagner uważał, że twórczość Ludwiga van Beethovena była niespełniona aż do IX Symfonii, w której dopiero osiągnął on moc przedstawiania idei - ale zarazem próbowali ocalić, szukając innego niż tradycyjny związku z poezją. Ten nowy związek, umożliwiający czystej muzyce instrumentalnej przedstawianie idei estetycznych, został zrealizowany w poetyckich miniaturach fortepianowych Roberta Schumanna, poematach symfonicznych Franza Liszta i symfonii programowej Hectora Berlioza. W tym kontekście filozoficznym sławny spór między muzyką programową a absolutną nie powinien być interpretowany jako spór o autonomię muzyki, nikt bowiem w tym sporze autonomii muzyki nie kwestionował, ale jako spór o zdolność muzyki instrumentalnej do samodzielnej istotności. Stanowisko samego Kanta w tej kwestii było pesymistyczne. Odwoływał się do przykładu muzyki instrumentalnej po to, by pokazać, w jaki sposób możliwe jest w sztuce uzyskanie piękna czystego. Podobnie jak arabeska także muzyka instrumentalna czy też czysta, określona przez Kanta precyzyjnie jako po prostu muzyka bez tekstu, może zatem podobać się bezinteresownie, pozapojęciowo, powszechnie, subiektywnie itp. Jest piękna pięknem czysto formalnym, jako pusta forma celowości, a zatem może podobać się w ten sam sposób co formy pozaartystyczne, na przykład dziki tulipan. Kant ma wątpliwości, czy dotyczy to każdej muzyki bez tekstu, czy przypadkiem logika formy muzycznej, odwołująca się przecież do wiedzy eksperckiej, nie wprowadza elementu pojęciowego, dlatego też odwołuje się do skrajnego przykładu Phantasien ohne Thema, czyli, zapewne, czysto instrumentalnych improwizacji bez ścisłej regulacji formalnej, których dostępnego nam utrwalenia możemy poszukiwać, jak sądzę, w utworach takich jak Fantazja c-moll Wolfganga A. Mozarta. W każdym razie, jeżeli jakakolwiek dziedzina sztuki nie odwołuje się do idei estetycznych, ale do czysto formalnego piękna, to jest to właśnie muzyka instrumentalna. W ten sposób jako jedyna dziedzina sztuki zrywa ona jakąkolwiek relację z językiem, stając się doświadczeniem czysto zmysłowym, a w końcu, jak Kant pisze wprost, „,więcej rozkoszowaniem się niż kulturą"21. Ostatecznie zatem, wbrew utożsamieniu Kantowskiej filozofii sztuki z analityką piękna, ścisły związek muzyki instrumentalnej z pięknem formalnym praktycznie usuwa ją z dziedziny sztuki, zdefiniowanej przecież jako sfera przedstawiania idei estetycznych, przesuwając ją do sfery zmysłowej przyjemności — przynajmniej w przypadkach skrajnych. Nie jest to wbrew popularnym zarzutom dowód niemuzykalności Kanta, ale nieuchronna konsekwencja przyjętego przezeń sposobu rozumienia samej sztuki, a może także - czego uniknie właśnie Herder — niewystarczającego położenia akcentu na językowy charakter pojęć, przez co relacja muzyki i pojęcia jawi się często u Kanta jako niewymagająca osobnej refleksji nad językiem. Herder, dla którego myślenie poza językiem nie istnieje, będzie musiał ująć tę kwestię inaczej.

21 Ibidem, s. 264. 


\section{Muzyka i język w metafizyce muzyki instrumentalnej}

Zanim jednak wrócimy do samego Herdera, trzeba wspomnieć o jeszcze jednym sposobie myślenia o relacji muzyka-język i o muzyce instrumentalnej, który wyrażony został w pismach niemieckich poetów, przede wszystkim Wilhelma Wackenrodera, Ludwiga Tiecka i Ernsta Theodora Amadeusa Hoffmana i który Carl Dahlhaus nazwał ,romantyczną metafizyką muzyki instrumentalnej”"22. Dokonując niezbędnego tutaj uogólnienia i nie rozróżniając między poglądami różnych autorów, można - idąc za Dahlhausem - wyłożyć ten sposób myślenia sumarycznie. Otóż język jako medium komunikacji jest tutaj uważany za podlegający dwóm ograniczeniom. Pierwsze stanowi niezdolność języka do wyrażenia stanów skrajnie idiosynkratycznych czy też w ogóle dotarcia do pojedynczości przedmiotu lub człowieka. To, co pojedyncze, nie podlega wypowiedzeniu, bez względu na jego charakter: Innerlichkeit, jak będzie się ją nazywać w następnym stuleciu, obejmuje doświadczenia zmysłowe i wewnętrzne cechujące się wyjątkowością i nie podlega językowej ekspresji w taki sam sposób - i z tych samych względów - co pojedynczość materialnego przedmiotu. Ograniczenie to wiąże się z faktem, że wszelki język nadający się do międzyludzkiej komunikacji musi być z konieczności językiem nazw ogólnych. Bez względu na stopień szczegółowości opisu nazwy ogólne uniemożliwiają dotarcie do tego, co niepowtarzalne, zawsze sprowadzając ową niepowtarzalność do operowania coraz bardziej zacieśniającym się kręgiem ogólności. Krąg ten jednak nie może zostać przekroczony, stąd też wysiłek wypowiedzenia tego, co indywidualne, w języku nazw ogólnych nie może zostać zamknięty i wszelka tego rodzaju próba musi być nieskończona, co niedługo później dokładnie opisze Hegel, ukazując niezamykalność opisu tego, co pojedyncze. Takiego zbliżenia się do indywidualności mógłby dokonać jakiś fantastyczny język złożony jedynie z nazw własnych, który - z oczywistych względów - nie mógłby być narzędziem poznania i komunikacji, jeśli w ogóle byłby językiem. Oto zatem pierwsze ograniczenie języka: niezdolność do wypowiedzenia tego, co niepowtarzalne, i zakomunikowania pojedynczości przedmiotu i życia człowieka.

Język jednak jest ograniczony także niejako z drugiej strony: nie mogąc dotrzeć do tego, co pojedyncze, nie potrafi on też wyrazić tego, co najbardziej ogólne, a więc pojęcia absolutu. Absolutna tożsamość i uniwersalność musi być $\mathrm{z}$ konieczności prezentowana $\mathrm{w}$ języku albo za pomocą nieadekwatnych pojęć, wywodzących swą możliwość znaczenia ze świata zmysłowego, albo apofatycznie, wyłącznie przez przeczenie, a więc za pomocą takich wyrażeń jak „niewyrażalne” itp.

22 Zob. C. Dahlhaus, Idea muzyki absolutnej, [w:] idem, Idea muzyki absolutnej i inne studia, przeł. A. Buchner, Kraków 1988, s. 9-166. 
Język jest więc skazany na pozostawanie w sferze pośredniej: odnosi się on do świata uporządkowanych zbiorów, uogólnionych cech i relacji, pozostawiając bieguny tego, co indywidualne i absolutne, poza własnym zasięgiem. Jak wyrazi to stulecie później Nietzsche, język jest uproszczeniem gwoli życiu, sprowadzając świat indywiduów do świata uporządkowanych zbiorów i relacji. Dzięki tej swojej cesze język jest skutecznym narzędziem działania człowieka w świecie, ale też pozostawia poza swoim zasięgiem to właśnie, co wydaje się szczególnie istotne dla poetów końca XVIII wieku. Problem Wackenrodera i Tiecka z językiem polega właśnie na tym, że okazuje się on niezdolny do tego, co interesuje ich najbardziej, czyli do ustanowienia relacji pomiędzy tym, co najbardziej indywidualne, i tym, co absolutne. Język staje więc na przeszkodzie zasadniczemu celowi tej poezji, realizując swą skuteczność w tej właśnie sferze, która poezję tę najmniej zajmuje.

Tego rodzaju problem z językiem prowadzi niemieckich poetów końca XVIII wieku do poszukiwania alternatywnego medium: okazuje się nim muzyka. Osiemnastowieczny zwrot poezji ku muzyce jest jednak odmienny od analogicznego zwrotu w poezji końca XIX wieku. Kiedy Paul Verlaine żądał od poezji ,muzyki nade wszystko", żądał zdobycia się na analogiczną do muzyki instrumentalnej autonomię formy, odrzucenia ekspresji i komunikacji na rzecz formalnego kształtowania brzmienia oraz podobnej niezależności od zewnętrznych, ,pozaartystycznych" celów i funkcji. Tymczasem dla Tiecka i Wackenrodera muzyka jest właśnie ideałem ekspresji i komunikacji, który potrafi zaradzić bolączkom języka. Muzyka jest sposobem ukształtowania doświadczenia zmysłowego i jest odbierana w sposób skrajnie zindywidualizowany. Nigdy nie można się dowiedzieć, co słyszy dany człowiek, kiedy słucha tej samej muzyki co my. Kompozytor nie aranżuje językowej ogólności, ale jest kimś na kształt reżysera idiosynkratycznych doświadczeń. Dzięki tej swojej cesze muzyka może przekraczać nieuchronną ogólność języka i w sposób bezpośredni docierać do człowieka w całej jego niepowtarzalności, ustanawiając komunikację między dwiema wyjątkowymi jednostkami z pominięciem całej sfery pośredniczącej (swoją drogą to właśnie ta domniemana zdolność muzyki wydaje się odpowiadać za powszechne złudzenie jej pozakulturowego charakteru; tę też zdolność miał bez wątpienia na myśli Beethoven w sławnej dedykacji do Missa Solemnis: „Z serca do serc” — trudno o bardziej dobitne wyrażenie przekonania o tym, że muzyka pomija wszystkie pośrednie stadia komunikacji i ustanawia niezmediatyzowaną więź między wyjątkowymi jednostkami). W ten sposób muzyka przekracza pierwsze ograniczenie języka i okazuje się skuteczna tu właśnie, gdzie język zawodzi.

Muzyka jednak potrafi także przekroczyć drugie z tych ograniczeń. Nie mając żadnego identyfikowalnego znaczenia, operując jednostkami bez odniesień przedmiotowych i wprowadzając między nie czysto formalne relacje, muzyka może odnosić się bezpośrednio do sfery tego, co pozazmysłowe, do najwyższej ogólności absolutu. Forma muzyczna jest właśnie czystą formą, czyli zbiorem relacji, który jest pusty i dzięki temu niezwiązany z żadną zmysłowością; formę muzyczną 
można rozumieć jako czystą strukturę języka, gdyby ten pozbawić odniesień do świata zmysłowego, czyli uwolnić od funkcji semantycznych. Myśl ta zostanie upowszechniona i rozwinięta w XIX wieku. Tę właśnie koncepcję wyraża sformułowana przez Johanna Forkela idea musikalische Logik: teza, iż powiązania formalne w muzyce realizują ten sam typ czysto formalnego wynikania i ten sam rodzaj konsekwencji co powiązania logiczne. Forkel sformułował tę myśl przy okazji refleksji nad organizacją formalną muzyki instrumentalnej Jana Sebastiana Bacha. Tak rozumiana muzyka może zatem reprezentować myśl w jej postaci absolutnej, nieuwięzionej przez zmysłowy świat. Muzyka przekracza więc drugie z ograniczeń języka i będąc zdolna wypowiedzieć zarówno to, co skrajnie indywidualne, jak i to, co absolutne, potrafi także ustanowić między tymi biegunami bezpośrednią więź.

Muzyka nie tylko zatem wiąże z sobą subiektywności niepowtarzalnych podmiotów (,z serca do serc”), ale też wiąże owe subiektywności z absolutnością Boga. Jej odniesienie do języka polega zatem na podwójnym tegoż języka przekraczaniu i budowaniu ekspresji i komunikacji tam właśnie, gdzie język zawodzi. Relację tę wyrażają takie frazy stosowane przez Tiecka i Wackenrodera w odniesieniu do muzyki, jak ,język uprzywilejowany” czy ,język ponad językiem”. Muzyka zatem nie jest prostą opozycją języka, ale dopiero jego pełną realizacją. Jest oczywiste, że aby muzyka mogła sprostać tym wymogom, musi uwolnić się od ograniczającego ją związku z poezją, która jako tekst wnosi do dzieła muzycznego wszystkie ograniczenia języka. Wartościowania są tu zatem właśnie odwrotne niż u Rousseau i Kanta, a muzyka instrumentalna staje się już nie ,,bardziej rozkoszowaniem się niż kulturą", lecz sztuką najwyższą, jako jedyna realizującą właściwe zadania sztuki. Zadaniem poety z kolei staje się w dużym stopniu apoteoza muzyki. Problem historyczny polega jednak na tym, co słusznie zauważył Carl Dahlhaus, że w momencie powstawania owej romantycznej metafizyki muzyki instrumentalnej nie istniała jeszcze tego rodzaju muzyka instrumentalna, która mogłaby sprostać jej wymogom. Wackenroder i Tieck nie tyle opisują jakąś konkretną muzykę, ile postulują muzykę przyszłości. Jest to więc myśl w poszukiwaniu swojego przedmiotu. Przełomowe znaczenie Ernsta Theodora Amadeusa Hoffmanna i jego włączenia się w ów nurt myślenia polegało nie tyle na oryginalnej koncepcji „fantazji”, stanowiącej estetyczny zamiennik religijnego absolutu, ile na wskazaniu przedmiotu takiej estetyki. Hoffmannowska recenzja $V$ Symfonii Beethovena to moment, w którym metafizyka muzyki instrumentalnej znajduje wreszcie swój przedmiot.

\section{Herder wobec problemu relacji muzyki i języka}

Uogólniając, można powiedzieć, że druga połowa XVIII wieku przyniosła kluczowe dla przyszłości przesunięcie w dyskusji nad relacją muzyki i języka: głów- 
nym terenem dociekań przestała być opera, jak było od Monteverdiego po Rousseau i Rameau, a stała się nim muzyka instrumentalna. W czasie tego przesunięcia zarysowały się dwa zasadniczo odmienne stanowiska. Pierwsze, reprezentowane między innymi przez Kanta, widziało w muzyce instrumentalnej zjawisko niepowiązane z językiem, ograniczające się do formalnej organizacji zmysłowości. $\mathrm{W}$ połączeniu $\mathrm{z}$ ideałem sztuki jako zmysłowego udostępniania pojęcia prowadziło to do jednoznacznie negatywnej oceny artystycznego potencjału muzyki instrumentalnej, nawet jeśli przyznawało tej muzyce rzadką w sztuce zdolność do realizacji czystego piękna. Drugie stanowisko widziało w muzyce instrumentalnej przekroczenie granic języka i zniesienie jego ograniczeń, przyznając jej najwyższy status artystyczny, uzasadniony zdolnością muzyki do wyrażania stanów niedostępnych językowi. Nie trzeba dodawać, że stanowisk tych nie sposób uzgodnić.

$\mathrm{Na}$ tak zarysowanej mapie problemowej filozofii muzyki w tym czasie stanowisko Herdera uderza nie tylko oryginalnością, ale też zasadniczym przeformułowaniem kluczowych problemów. U początku swej filozoficznej drogi, kiedy pisząc swoje Gaje krytyczne, Herder podzielał jeszcze w dużym stopniu transcendentalne i aprioryczne stanowisko Kanta, zbliżał się też do Kantowskich rozstrzygnięć i wartościowań w zakresie filozofii muzyki. Rewizja tych poglądów nastąpiła przede wszystkim w Listach teologicznych i najpóźniej pisanych partiach wspomnianych Gajów krytycznych ${ }^{23}$. Zmianę stanowiska Herdera można wiązać z przemyśleniem pytania postawionego przez jego najważniejszego oprócz Kanta nauczyciela, czyli Johanna Georga Hamanna. Pytanie to można wyrazić następująco: język jest niewątpliwym medium myślenia. Czy myślenie może mieć także inne media? Jest to $\mathrm{w}$ dużym stopniu pytanie o status nielingwistycznych dziedzin sztuki i o ich zdolność do stawania się medium myśli. Odpowiedź Hamanna była skrajnie optymistyczna, założył on bowiem, że każda forma ukształtowania zmysłowości jest sposobem dawania wyrazu ludzkiemu doświadczaniu świata, które - jako doświadczenie rozumiejące — nazywamy myśleniem. Wyraz tego myślenia nie jest jednak niezależny od specyfiki medium, w jakim się dokonuje. Jeśli więc zarówno malarstwo, jak i muzyka są na równi z poezją czy językiem w ogóle ekspresjami rozumiejącego doświadczenia świata i siebie, to ze względu na odmienność mediów owej ekspresji nie istnieje między nimi relacja wzajemnej przekładalności. Myślenie dokonujące się w medium języka i w medium obrazu jest na równi myśleniem, ale ze względu na nieprzekraczalną specyfikę medium nie może być wzajem do siebie zredukowane.

23 Główne pisma estetyczne Herdera zostały zebrane w Selected Writings on Aesthetics, red. G. Moore, Princeton 2006. Poniższe rekonstrukcje poglądów Herdera na temat muzyki opieram na tym właśnie zbiorze. Korzystam także z uporządkowania głównych tez estetycznych Herdera, jakiego dokonał Michael Forster w przywoływanym wcześniej artykule z Stanford Encyclopedia of Philosophy. Niestety, nie ma wciąż zbiorczego wydania rozpraw estetycznych Herdera w języku polskim. 
To niezwykle szerokie i w odniesieniu do niejęzykowych mediów ekspresji bardzo optymistyczne, jak powiedzieliśmy, stanowisko Hamanna nie zostało przez Herdera przyjęte. Zanim przyjrzymy się konsekwencjom stanowiska samego Herdera, przedstawmy jego zasadnicze rozstrzygnięcia. Twierdzi zatem Herder, że:

1. Myśl jest zjawiskiem specyficznie językowym, ponieważ jej struktura jest nieuchronnie uzależniona od relacji syntaktycznych, gramatycznych i przede wszystkim semantycznych języka. To te relacje odpowiadają za ukształtowanie się w myśli zależności logicznych, a nie występują one w żadnym innym medium niż język. Media wizualne czy dźwiękowe nie mają tego rodzaju struktury, która byłaby tożsama z logiczną strukturą myślenia. Struktura języka i struktura myślenia nie są względem siebie analogiczne, lecz są po prostu tą samą strukturą. Nie istnieje zatem kryterium pozwalające odróżnić myśl od zawierającej ją wypowiedzi językowej, a myślenie nie jest możliwe poza medium języka. Traktowanie innych niż język środków ekspresji jako mediów myślenia może być jedynie niedokładną metaforą i nie sprzyja wyjaśnieniu specyfiki nielingwistycznych dziedzin sztuki. Tezę tę dokumentują przytaczane wcześniej wypowiedzi Herdera z Rozprawy o pochodzeniu języka.

2. Nie będąc mediami myślenia, wypowiedzi wizualne czy dźwiękowe, takie jak malarstwo czy muzyczne dzieła sztuki, mają jednak dla nas znaczenie i mogą być zrozumiałe. Oznacza to, że — jeśli język jest jedynym medium myślenia — wypowiedzi te muszą pozostawać w pewnej szczególnej relacji względem wypowiedzi językowych i nie są od języka niezależne. Problemem jest nie to, w jaki sposób myślenie miałoby dokonywać się w medium malarstwa czy muzyki, ale to, jakiego rodzaju związek z językiem umożliwia malarstwu lub muzyce bycie dla nas czymś znaczącym i zrozumiałym.

3. Dzieła nielingwistycznych dziedzin sztuki są zrozumiałe dzięki dwóm sposobom ich prefiguracji. Najpierw ich organizacja formalna, podobnie jak w wypadku sztuk lingwistycznych, wyznacza dla nas pierwszą ramę pojmowalności dzieła, gdyż formalna struktura dzieł sztuki wbrew pozorom nie jest wyjątkowa. Formalna sensowność dzieł sztuki możliwa jest dzięki temu, że zarówno tworzenie, jak i odbiór takiego dzieła nie dokonują się w abstrakcyjnej przestrzeni sztuki po prostu, ale w konkretnie historycznie i kulturowo ukształtowanym polu, zdefiniowanym przez artystyczne gatunki. To, że nie widzimy po prostu obrazu, ale martwą naturę lub portret, że nie czytamy poezji, ale tragedię lub sonet, że nie słuchamy muzyki, lecz pieśni lub sonaty - czyni dla nas ich strukturę wstępnie zrozumiałą, łącznie z odchyleniami od naszych oczekiwań i przekraczaniem granic gatunków. Rama zrozumiałości wyznaczana przez gatunki artystyczne jest historycznie zmienna i trwałość terminów może zakrywać zmienność samych gatunków, co prowadzi do sytuacji, gdy paradoksalnie podział pola sztuki na gatunki może - zamiast ułatwiać - utrudniać zrozumienie indywidualnych dzieł sztuki. Tak na przykład pojęcie tragedii, ukształtowane na podstawie twórczości tragików attyckich, tworzy barierę w zrozumieniu tragedii szekspirowskiej, ponieważ mimo tożsamości 
terminu tragedie starogrecka i w tatrze elżbietańskim są odmiennymi gatunkami artystycznymi. To rozumowanie Herdera dotyczy w całej rozciągłości także muzyki, łącznie z uwagą o historycznej zmienności gatunków (dziewiętnastowieczne rozumienie sonaty może być jedynie przeszkodą w rozumieniu na przykład sonat Arcangela Corellego).

4. Drugim i najważniejszym filarem zrozumiałości dzieł nielingwistycznych dziedzin sztuki jest to, iż opierają się one na językowej prefiguracji znaczeń, czyli że standardy i znaczenia tych dzieł zostały wstępnie określone w praktyce językowej. Ujmując sprawę inaczej, nielingwistyczne dziedziny sztuki, takie jak muzyka instrumentalna, dokonują się w świecie, w którym pewna wspólnota dokonała językowego, a więc refleksyjnego przedstawienia. Jak wiemy, taką właśnie językową wspólnotę wraz z określeniem miejsca, jakie zajmuje w nim człowiek, nazywa Herder kulturą. To językowe wstępne określenie znaczeń świata, które jest zawsze zmienne i otwarte na historię, zawiera także wstępne określenie możliwych znaczeń tak specyficznych istności jak obraz lub dzieło muzyczne. Te są więc zrozumiałe dzięki temu, że stanowią indywidualne artykulacje pewnych znaczeń już dla wspólnoty możliwych, bo określonych w prefiguracji językowej. Niepowtarzlaność nielingwistycznego dzieła sztuki w jego odniesieniu do językowej prefiguracji znaczeń wygląda więc tak samo jak w jego odniesieniu do istniejących gatunków wypowiedzi artystycznej. Z punktu widzenia Herdera zatem dwa główne stanowiska zajmowane w XVIII wieku w sporze o muzykę instrumentalną, z jednej strony stanowisko Rousseau i Kanta, z drugiej - stanowisko Tiecka i Wackenrodera, można ująć jako przykłady odmiennej językowej prekonfiguracji możliwych znaczeń muzyki instrumentalnej. Tak rozumiane nie tyle odpowiadają one na pytanie o to, czym ta muzyka jest, ile wyznaczają odmienne i konfliktowe kultury muzyczne. Romantyczna metafizyka muzyki instrumentalnej nie wyjaśnia zatem muzyki, ale konfiguruje jej możliwe znaczenie i - co kluczowe - dokonuje tego w języku: określenie muzyki jako czegoś językowego i przekraczającego język jest możliwe tylko w działaniu językowym i muzyka może być „ponad językiem” dla wspólnoty, która w ten sposób ją zdefiniuje. Nie oznacza to, że metafizyka ta jest po prostu fałszem czy iluzją: jest ustanowieniem pewnej kultury, które jako ustalenie znaczeń nie może się dokonać poza językiem.

5. Nie tylko jednak wytwarzanie dzieł nielingwistycznych dziedzin sztuki jest zakorzenione w i umożliwione przez językową prefigurację znaczeń. Także percepcja takich dzieł sztuki ma charakter językowy, o ile tylko przekracza horyzont ściśle indywidualnej reakcji somatycznej i wchodzi w przestrzeń międzyludzką albo w pole samorozumienia podmiotu. Próba zrozumienia własnego doświadczenia estetycznego nie może mieć charakteru innego niż interpretacja dokonująca się w języku. Każde wypowiedzenie znaczenia dowolnego tworu niejęzykowego, w tym muzycznego, na własny użytek lub względem innej osoby musi mieć charakter wypowiedzi językowej, a więc na mocy tożsamości języka i myślenia - charakter myślenia. Więcej nawet, ze względu na językowy charakter 
ludzkiej samoświadomości nie jest możliwe prawdziwie pozajęzykowe doświadczenie zmysłowe, ponieważ sama ludzka percepcja wiąże stany zmysłów z ich językowym określeniem, a więc już owa percepcja zmysłowa jest lingwistyczna. Oznacza to, że Hamann uległ pewnemu złudzeniu i uznając muzykę czy malarstwo za medium myślenia, przypisał samym sztukom nielingwistycznym coś, co stanowi element każdej możliwej ich percepcji. Myślenie nie jest zatem zawarte w muzyce, ale w jej odbiorze. Ta lingwistyczna percepcja pozostaje oczywiście uzależniona od wspomnianej wcześniej językowej prefiguracji znaczeń dla całości sztuk nielingwistycznych. Ostatecznie zatem twory sztuk nielingwistycznych zostają wyposażone w zawartość myślową na mocy podwójnej zależności od dwóch wzajem na siebie oddziałujących biegunów: gruntującego owe sztuki językowego określenia możliwych znaczeń oraz językowego, a więc myślowego charakteru ich percepcji.

Tezy 4 i 5, traktowane łącznie, są konsekwencjami tez zawartych w Rozprawie o pochodzeniu języka, gdzie Herder rozpatruje nieuchronnie językowy charakter wszelkiego ludzkiego doświadczenia zmysłowego. Wiąże się to z Herderowskim utożsamieniem rozumności z językowością i uznaniu rozumności za gatunkową cechę człowieka. W związku z tym ludzkie postrzeganie nie ma nigdy charakteru instynktownego, jak postrzeganie zwierzęce, ale charakter refleksyjny - a więc językowy: „Jeśli rozum nie jest oddzielną, pojedynczo działającą siłą, lecz własnym kierunkowskazem wszystkich sił swego gatunku, to człowiek musi go posiadać w pierwszym okresie życia, ponieważ jest człowiekiem" ${ }^{24}$. Nie istnieje tego rodzaju ludzkie doświadczenie zmysłowe, nawet dziecięce, które nie byłoby kształtowane przez rozumność, a więc językowość:

Ale przecież najbardziej zmysłowy stan człowieka był jeszcze ludzki, a więc jeszcze ciągle działała w nim rozwaga, jedynie w stopniu mniej dostrzegalnym; najmniej zmysłowy stan zwierząt był jeszcze zwierzęcy i jako taki przy całej wyrazistości swych myśli nigdy nie zdradzał rozwagi w pojęciu ludzkim ${ }^{25}$.

W szczególności zaś owa rozumność, refleksyjność czy też rozwaga - a więc, raz jeszcze, językowość — dotyczy każdego możliwego ludzkiego postrzeżenia zmysłowego, zarówno w odniesieniu do świata zewnętrznego, jak i własnych stanów wewnętrznych. Słyszenie muzyki nie może oczywiście być w tej mierze żadnym wyjątkiem:

Człowiek demonstruje refleksję, kiedy ze wszystkich stojących mu przed oczami urojonych obrazów, które przesuwają się w jego zmysłach, potrafi skoncentrować się na jednej chwili czuwania, zatrzymać się dobrowolnie na jednym obrazie, rozumnie i spokojnie zająć się nim i wysegregować cechy wskazujące, że jest to ten przedmiot, a nie inny. Demonstruje refleksję, kiedy nie tylko bystro czy jasno potrafi rozpoznać wszystkie właściwości, lecz potrafi jedną lub kilka jako różniące się właściwości rozpoznać w sobie; pierwszy akt tego spostrzeżenia daje wyraźne

\footnotetext{
24 J.G. Herder, Rozprawa..., s. 84.

25 Ibidem, s. 86-87.
} 
pojęcie, jest to pierwszy sąd duszy. I — w jaki sposób doszło do spostrzeżenia? Przez cechę, którą musiał wyodrębnić i która wyraźnie uderzyła go jako cecha rozwagi. A więc zawołajmy

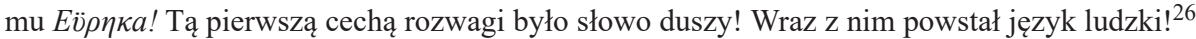

Tych pięć tez, jeśli przemyśleć je w kontekście dwóch innych twierdzeń Herdera o historycznym charakterze ludzkiej rzeczywistości i o kształtowaniu znaczeń poprzez społeczne użycie jednostek znaczących, pozwala wyciągnąć dwa następujące wnioski:

1. Dzieła nielingwistycznych dziedzin sztuki nie są czymś, co po prostu egzystuje w kulturowej przestrzeni, określonej przez dwa wymienione powyżej bieguny językowego odniesienia do ich dzieł, lecz czymś, co podlega użyciu, czym ludzie posługują się w określony sposób i w określonych sytuacjach. Pod tym ostatnim względem nie różnią się od języka, który także jest czymś, co podlega użyciu, i dopiero w tym użyciu się konstytuuje. Znaczenia językowe nie są zdaniem Herdera czymś, co byłoby w języku istotowo zawarte lub określone na mocy konieczności, ale jedynie sposobami używania słów i wyrażeń. Jeśli tym, co jako jedyne może wyposażać w znaczenia, jest użycie - Herder podziela tutaj późniejsze stanowisko Ludwiga Wittgensteina i powittgensteinowskiej filozofii analitycznej - to także znaczenia dzieł nielingwistycznych dziedzin sztuki zyskują znaczenia w toku bycia używanymi. Używane są jednak w polu już zakreślonym przez prekonfigurację językową. Jeśli rozważyć jednocześnie dwie tezy Herdera, a mianowicie, że wypowiedzi nielingwistyczne są wyposażane w znaczenie przez jego językową prefigurację i przez językowy charakter percepcji oraz że wszelkie znaczenie jest sposobem użycia, to wynika z tego, że znaczenie tworów takich jak dzieło muzyczne powstaje w wyniku procesu użycia tych tworów wewnątrz pewnych praktyk językowych. Sytuacja nielingwistycznych dziedzin sztuki nie jest więc znowu aż tak odległa od sytuacji sztuk językowych, które, choć mogą jako językowe mieć własną zawartość myślową, to przecież podlegają tym samym ogólnym zasadom prefiguracji językowości percepcji i użycia. Wynika stąd, że zasadniczo proces rozumienia dzieł sztuki jest w swoim przebiegu bardzo złożony bez względu na to, o jakiej dziedzinie sztuki mowa. Zatem nie ma powodu, by postulować odmienne metody rozumienia i poznawania dla różnych dziedzin sztuki. Potrzebna jest jedna hermeneutyka o wspólnych zasadach. Hermeneutyka ta obejmuje całe pole sztuki i nie istnieją takie wypowiedzi artystyczne, które by jej nie podlegały.

2. Jeżeli znaczenie i percepcja nielingwistycznych dzieł sztuki są zależne od ich językowej prefiguracji, to stopień złożoności tego znaczenia, a więc ich zdolność do posiadania zawartości myślowej zależy bezpośrednio od stopnia wypracowania tejże prefiguracji językowej. Otóż prefiguracja ta może występować w biegunowych postaciach albo jako szczątkowa (hipotetycznie można wyobrazić sobie nawet brak takiej prefiguracji), albo przybierać postać złożonych sy-

${ }^{26}$ Ibidem, s. 87-88. 
stemów myślowych takich, jak na przykład estetyki filozoficzne. Bieguny te wyznaczają skrajne możliwości percepcji niejęzykowego dzieła sztuki: możliwość reakcji czysto zmysłowo-emocjonalnej w wypadku braku lub szczątkowości odpowiedniej prefiguracji językowej oraz możliwość złożonej reakcji interpretacyjnej w wypadku odpowiedniego bogactwa tejże prefiguracji. W toku rozwoju historycznego językowe prefiguracje znaczeń sztuk nielingwistycznych wykazują rosnącą złożoność, która pociąga za sobą przesuwanie się możliwych reakcji percepcyjnych od pierwszego do drugiego z możliwych biegunów. Historyczny rozwój sztuk można zatem określić za Herderem jako rozwój „od uczucia do myśli”: nie chodzi tu jednak o jakąś immamentną dynamikę sztuki, ale właśnie o zmianę sposobu rozumienia dzieł sztuki w wyniku rozbudowy prefiguracji językowej ich znaczeń, związaną bardziej z rozwojem języka niż sztuki samej. W odniesieniu do muzyki instrumentalnej oznaczałoby to rozwój od tejże muzyki jako przyjemności zmysłowej do tej samej muzyki jako wyposażonej w zawartość myślową. Otóż przemiana ta dokonała się właśnie w drugiej połowie XVIII wieku i z perspektywy Herderowskiej można zrozumieć, że ani Rousseau nie był w swoim rozumieniu muzyki instrumentalnej naiwny, ani Kant - niemuzykalny, lecz że ich rozumienie muzyki instrumentalnej wyznaczane było przez taką prefigurację możliwych znaczeń tej muzyki, która niemal z dnia na dzień miała stracić aktualność. Opinie Rousseau i Kanta wyrażone w XVIII wieku byłyby świetnie zrozumiane w wieku XVI, ale na początku XIX wieku były już głosami z zamierzchłej epoki, bowiem właśnie dzięki takim ludziom jak Wackenroder, Tieck i Hoffmann dokonano całkowitej przebudowy językowej prefiguracji znaczeń dla muzyki instrumentalnej i przesunięto ją ze sfery uczucia do sfery myśli. Reasumując, stanowisko zajęte przez Herdera w osiemnastowiecznym sporze o relację między muzyką a językiem i o wynikający z tej relacji status muzyki instrumentalnej można - opierając się zarówno na bezpośrednich wypowiedziach Herdera na ten temat, jak i na tym, co wynika z innych jego tez, głównie z zakresu filozofii języka i filozofii kultury - wyrazić następująco: muzyka instrumentalna jako niejęzykowa, nie ma samodzielnych znaczeń, ale jest w te znaczenia wyposażona na mocy trzech zależności, to jest zależności od językowej prefiguracji znaczeń, od językowego charakteru percepcji i od sposobów używania jej dzieł — zasadniczo od bycia przedmiotem doświadczenia istoty refleksyjnej, a więc $\mathrm{z}$ definicji językowej, jaką jest człowiek.

Równie jednak istotne jak rekonstrukcja stanowiska Herdera, jak widać wysoce odrębnego od dwóch głosów dominujących w osiemnastowiecznej debacie, jest wskazanie dwóch kluczowych konsekwencji tego stanowiska, które w badaniu muzyki zaczęły zyskiwać szersze zrozumienie dopiero pod koniec XX wieku.

Po pierwsze, w świetle stanowiska Herdera znaczenie muzyki nie może zostać wyjaśnione z punktu widzenia jakiejkolwiek estetyki, która przyjęłaby transcendentalną lub jakąkolwiek inną aprioryczną perspektywę. Nie jest też możliwe systemowe ujęcie tego problemu. Znaczenie muzyki jest kwestią empiryczną w ro- 
zumieniu nauk historycznych i podlega jedynie niesystemowemu, historycznemu opisowi. Do opisu takiego nie jest przy tym zdolna taka historia muzyki, która dokonywałaby jej nadmiernej autonomizacji i rozpatrywała zjawiska muzyczne w oderwaniu od innych zjawisk kulturowych. Jeżeli muzyka może być wyposażona $\mathrm{w}$ znaczenia jedynie dzięki odniesieniu do tychże znaczeń językowych prefiguracji, to same te prefiguracje dokonywane są często - dla wielu wspólnot z zasady - w praktykach innych niż muzyczna. Znaczenia muzyki mogą być i rzeczywiście są wstępnie określane przez mit, doktryny religijne, filozoficzne i estetyczne, ideologie polityczne oraz przez sposoby posługiwania się muzyką w całościach takich jak obrzęd, święto, praktyki dystynkcji społecznej czy tak zwane autonomiczne praktyki muzyczne, jak na przykład koncert filharmoniczny, który przecież także jest językowo prefigurowanym sposobem posługiwania się muzyką, a więc sposobem wyposażania jej w znaczenie. Więcej jeszcze, żadne tego rodzaju wyjaśnienia nie mogą mieć charakteru uniwersalnego, a ich ważność jest ograniczona historycznie i geograficznie oraz przez wewnętrzne zróżnicowanie i wzajemne oddziaływania wchodzących w rachubę wspólnot. Muzyka jako twór znaczący zatem jest przedmiotem odpowiednio ukierunkowanej historii kultury i etnografii, a historia muzyki zdolna do jej zrozumienia musi być pytającą o muzykę ogólną historią kultury. Charakterystyczne, że z konieczności przyjęcia tego rodzaju stanowiska już dawno temu zdano sobie sprawę w historii sztuk wizualnych (przypomnijmy hasło Maxa Dvořaka: Kunstgeschichte als Geistesgeschichte, co prawda odwołujące się do Wilhelma Diltheya, a nie Herdera, jak wyobrazić sobie jednak Diltheya bez Herdera?), podczas gdy pierwszą szeroko zakrojoną próbą tego rodzaju w historii muzyki, oczywiście przygotowaną przez wiele prac o skromniejszym zakresie, jest dopiero The Oxford History of Western Music Taruskina.

Druga konsekwencja jest taka oto, że wszelka muzyka jest zrozumiała dzięki pewnej towarzyszącej jej hermeneutyce, a więc hermeneutyka muzyczna nie jest opcjonalna. Tutaj potrzebne jest słowo wyjaśnienia. Termin ,hermeneutyka muzyczna", co jest historycznie zrozumiałe, został na trwałe skojarzony z koncepcją Hermanna Kretzschmara, która rozciągnęła na całość muzyki paradygmat romantycznej muzyki programowej, to jest widzi samą możliwość hermeneutyki w domniemaniu, iż za każdym możliwym tworem muzycznym stoi zawarty w nim implicite program poetycki, którego wydobycie jest zadaniem interpretatora. Oczywiście nie o taką hermeneutykę muzyczną tutaj idzie. Chodzi o to, że nawet przekonanie, że muzyka nie ma znaczeń, jest asemantyczna, niejęzykowa i nie podlega innej postaci rozumienia niż strukturalna analiza formy — jest pewnym zbiorem reguł rozumienia muzyki, to jest, w rozumieniu Herdera, pewną językową prefiguracją znaczenia muzyki, a więc wyznacza określoną hermeneutykę. Muzyka może być rozumiana jako twór czysto formalny jedynie wewnątrz hermeneutyki, która takie jej rozumienie ustanowi. 
Jedną jeszcze rzecz trzeba podkreślić w odniesieniu do stanowiska Herdera w kwestiach filozofii muzyki. Otóż zestawiony z Rousseau, Kantem czy poetami okresu burzy i naporu Herder wydaje się dziwnie niezainteresowany udzieleniem rozstrzygającej odpowiedzi na pytania swojej epoki. Zamiast tego proponuje taką koncepcję, wewnątrz której zrozumiałe jest dopiero, jak są możliwe stanowiska Rousseau, Kanta czy poetów burzy i naporu i jakie są granice ważności tych stanowisk. Zajmuje więc rodzaj metapozycji, a spór filozoficzny jego własnej epoki staje się dla niego materiałem do historii kultury. Nie znaczy to, że Herder kwestie te bagatelizuje lub jest „niezaangażowany”. Jego samotna wówczas walka o godność i wagę kultur nieelitarnych jest daleka od braku zaangażowania i ściśle związana z jego apologią demokracji w filozofii polityki. Stanowisko Herdera wynika bowiem z uświadomienia sobie, że sama filozofia jest praktyką prefigurowania sensu świata i podlega historyczno-kulturowemu badaniu jak każda praktyka sensotwórcza. Nadawanie sensu światu i ludzkiej wspólnocie, którego pierwotną postacią jest, zdaniem Herdera, pieśń ludowa, przybiera w filozofii jako praktyce postać bardziej złożoną, choć niekoniecznie bardziej autentyczną. Herderowska metapozycja wynika właśnie z filozoficznego uświadomienia sobie kulturowych zadań filozofii.

\section{Instrumental music and language. Herder's position in the 18th-century music and aesthetic debate}

\section{Abstract}

Johann Gottfried von Herder's philosophy of music deals with two basic threads of the 18th-century musico-aesthetic debate: the music-language relationship and the status of instrumental music. When placed in the context of different standpoints of this debate, Herder's views prove not only their originality, but above all their ability to transcend the horizon of the debate itself and to explain the possibility and validity of other solutions. Herder's conception is founded on three elements: the concept of linguistic prefiguration of meanings for instrumental music, the idea of a linguistic character of perception, and the vision of unified hermeneutics for non-linguistic arts.

Keywords: Herder, culture, language, hermeneutics, instrumental music, aesthetics 
Bibliografia

Beiser F.C., Enlightenment, Revolution, and Romanticism: The Genesis of Modern German Political Thought, 1790-1800, Cambridge 1992.

Dahlhaus C., Idea muzyki absolutnej, [w:] idem, Idea muzyki absolutnej i inne studia, przeł. A. Buchner, Kraków 1988, s. 9-166.

Forster M., Johann Gottfried von Herder, [hasło w:] The Stanford Encyclopedia of Philosophy (Summer 2019 Edition), red. E.N. Zalta, https://plato.stanford.edu/archives/sum2019/entries/ herder/ (dostęp: 4.03.2021).

Fijałkowski M., Pieśń ludowa u Johanna Gottfrieda Herdera. Impulsy, źródła, recepcja, Warszawa 2017.

Fubini E., Historia estetyki muzycznej, przeł. Z. Skowron, Kraków 2002.

Herder J.G., Selected Writings on Aesthetics, red. i przeł. G. Moore, Princeton 2006.

Herder J.G., Wybór pism, przeł. M. Jaroszewski, Wrocław 1987.

Johnson M., Lakoff G., Metafory w naszym życiu, przeł. T. Krzeszowski, Warszawa 2020.

Kant I., Krytyka władzy sądzenia, przeł. J. Gałecki, Warszawa 1986.

Kłoskowska A., Socjologia kultury, Warszawa 1981.

Nietzsche F., O prawdzie i ktamstwie w pozamoralnym sensie, [w:] idem, Pisma pozostate 1862 1875, przeł. B. Baran, Kraków 1993.

Palisca C.V., The Artusi-Monteverdi Controversy, [w:] The Monteverdi Companion, red. A. Denis, N. Fortune, New York 1972.

J.J. Rousseau, Szkic o pochodzeniu języków, przeł. B. Banasiak, Kraków 2001.

Sadie S., Vincenzo Galilei, [hasło w:] The New Grove Dictionary of Music and Musicians, t. 20, London 1980.

Skowron Z., Myśl muzyczna Jeana-Jacques'a Rousseau, Warszawa 2010.

Taruskin R., The Oxford History of Western Music, t. 3. Music in the Nineteenth Century, Oxford-New York 2010.

Zammito J.H., Herder and Historical Metanarrative: What's Philosophical about History?, [w:] A Companion to the Works of Johann Gottfried Herder, red. H. Adler, W. Koepke, Rochester-New York 2009, s. 65-92.

Krzysztof Moraczewski - dr hab., prof. UAM. Pracownik Instytutu Kulturoznawstwa Uniwersytetu im. Adama Mickiewicza w Poznaniu, kierownik Pracowni Badań nad Kulturą Artystyczną. Zajmuje się zagadnieniami teorii kultury oraz teorii i historii kultury artystycznej, głównie kultury muzycznej. Autor monografii Sztuka muzyczna jako dziedzina kultury i Cultural Theory and History: Theoretical Issues. Redaktor prac zbiorowych, autor wielu artykułów naukowych. Czynny jako krytyk muzyczny i popularyzator wiedzy o kulturze.

kmoracz@amu.edu.pl 